\title{
International Study on Artemia*. XXVI. Food Value of Nauplii from Reference Artemia Cysts and Four Geographical Collec- tions of Artemia for Mud Crab Larvae**
}

\author{
C. R. Seidel ${ }^{1}$, D. M. Johns ${ }^{1,2}$, P. S. Schauer ${ }^{1,2}$ and C. E. Olney ${ }^{1}$ \\ 1 Department of Food Science and Technology, Nutrition and Dietetics, University of Rhode Island, Kingston, Rhode Island 02881, USA \\ 2 United States Environmental Protection Agency, Environmental Research Laboratory, South Ferry Road, Narragansett, Rhode Island 02882, \\ USA
}

ABSTRACT: Nauplii from 4 commercially available geographical collections of Artemia and nauplii hatched from the Reference Artemia Cysts were compared for their effects on survival and growth of Rhithropanopeus harrisii larvae. In addition, nauplii from these sources were analyzed for their fatty acid and chlorinated hydrocarbon contents. Despite differences in the amounts of a few important polyunsaturated fatty acids $(18: 3 \omega 3,20: 5 \omega 3)$, as well as in the chlorinated hydrocarbon content, there was little variation in the survival and development rates of $R$. harrisii fed these Artemia sources as food. However, growth of $R$. harrisii from hatching to megalopa was significantly higher on the strain from France, intermediate in the Reference, Brazil and Chinese strains, and poorest on the Chaplin Lake (Canada) strain. The Reference strain is shown to be one of the better sources of Artemia nauplii with regard to their use in crab culture and therefore represent a good standard for future research studies.

The brine shrimp Artemia is extensively used as food source in the culture of larval fish and crustaceans. Although relatively expensive, Artemia is convenient to use and supports better larval development and survival than other live or artificial diets tested (Sulkin and Norman, 1976; Manzi and Maddox, 1980). There are, however, differences in Artemia composition that may alter the nutritional effectiveness of some commercially available sources of Artemia (Olney et al., 1980; Schauer et al., 1980).

The research reported here is a continuation of the effort initiated by the International Study on Artemia

\footnotetext{
- International Interdisciplinary Study on Artemia strains coordinated by the Artemia Reference Center, State University of Ghent, Belgium

- Contribution No. 2069 Rhode Island Agriculture Experimental Station, University of Rhode Island and Contribution No. 244 United States Environmental Protection Agency, Environmental Research Laboratory, Narragansett, Rhode Island
}

(Sorgeloos, 1980a) to characterize the biochemical composition and nutritional performance of commercially available sources of Artemia. Collections of Artemia tested were obtained from the following geographic areas: (1) Lavalduc, France, harvested 1979; (2) Tientsin, People's Republic of China, harvested 1979; (3) Chaplin Lake, Canada, harvested 1979; (4) Macau, Brazil, harvested 1978; (5) Reference Artemia Cysts (RAC), provided by the Artemia Reference Center, Ghent, Belgium. The RAC have been proposed as intercalibration material in studies using Artemia nauplii as food source (Simpson et al., 1980; Sorgeloos, 1980b).

Methods used for the detection of chlorinated hydrocarbons, as well as results of lipid analyses have been reported elsewhere (Olney et al., 1980; Schauer et al., 1980). For both of these analyses samples were run in triplicate.

Newly-hatched zoeae of the mud crab Rhithropanopeus harrisii were used as nutritional bioassay material. Methods for laboratory maintenance of gravid adults, procurement of newly-hatched zoeae and the exerpimental design used in this study have been described in detail by Johns et al. (1980).

The present study provides further information on variability in the biochemical composition and food value between different geographical sources of Artemia. Differences were found in fatty acid composition, total lipid content and chlorinated hydrocarbon contamination levels. The most noteworthy differences between the 5 Artemia sources were the higher level of 18:3w3 in the Canadian and French strains and the high level of 20:5 13 in the Chinese strain (Table 1). All strains contained substantial levels of $20: 5 \omega 3$. (>8\%). The total lipid levels of RAC, Brazilian and Chinese 
Table 1. Artemia spp. Weight percent fatty acid composition of various geographical collections of newly-hatched nauplii. nd: not detected

\begin{tabular}{|c|c|c|c|c|c|c|}
\hline FAME & RAC & Brazil $^{1}$ & & Canada & China & France \\
\hline $14: 0$ & 1.79 & 1.57 & & 0.83 & 1.80 & 1.73 \\
\hline $14: 1$ & 2.92 & 0.81 & & 1.67 & 2.24 & 3.03 \\
\hline $16: 0$ & 12.70 & 15.42 & & 9.99 & 11.40 & 11.90 \\
\hline $16: 1 \omega 7$ & 16.78 & 10.79 & & 9.03 & 19.06 & 11.34 \\
\hline $16: 3 \omega 4 / 17: 1 \omega 8$ & 4.33 & 3.88 & & 1.47 & 2.54 & 2.20 \\
\hline $18: 0$ & 4.07 & 2.79 & & 5.12 & 3.99 & 4.21 \\
\hline $18: 1 \omega 9$ & 30.37 & 35.89 & & 28.24 & 26.81 & 24.73 \\
\hline $18: 2 \omega 6$ & 9.62 & 9.59 & & 7.95 & 4.68 & 6.14 \\
\hline $18: 3 \omega 3$ & 2.55 & 4.87 & & 19.87 & 7.38 & 20.90 \\
\hline $18: 4 \omega 3$ & nd & 0.96 & & 1.60 & 1.26 & 2.04 \\
\hline $20: 2 \omega 6 / 20: 3 \omega 6$ & 0.20 & 2.82 & & 0.44 & 0.15 & 1.13 \\
\hline $20: 3 \omega 3 / 20: 4 \omega 6$ & 5.82 & nd & & 4.21 & 3.34 & 2.45 \\
\hline $20: 5 \omega 3$ & 8.45 & 8.98 & & 9.52 & $\underline{15.35}$ & 8.01 \\
\hline TOTAL $\%$ & 99.60 & 98.37 & & 99.94 & 100.00 & 99.81 \\
\hline $\begin{array}{l}\text { Total Lipid } \\
\mathrm{mg} \mathrm{g}^{-1} \text { dry wt. }\end{array}$ & $209.4 \pm 24.0$ & $202.0 \pm 8.0$ & & $142.9 \pm 34.0$ & $201.7 \pm 0.3$ & $152.1 \pm 29.0$ \\
\hline${ }^{1}$ Data from Schauer & $(1980) ; 0.67 \%$ & $15: 0$ and $0.52 \%$ & $20: 1$ & 9 were also present & & \\
\hline
\end{tabular}

Table 2. Artemia spp. Chlorinated hydrocarbon content of various geographical collections of newly-hatched nauplii. Results expressed as $\mathrm{ng} \mathrm{g}^{-1}$ wet weight (ppb). nd: not detected

\begin{tabular}{|c|c|c|c|c|c|}
\hline & $\mathrm{RAC}$ & Brazil & Canada & France & China \\
\hline $\mathrm{HCB}$ & 0.3 & 0.1 & 0.3 & 1.8 & 97.0 \\
\hline РCB 1016 & 1.0 & 5.3 & 6.2 & 8.6 & 6.3 \\
\hline PCB $1254 / 1260$ & 0.2 & 1.6 & 5.6 & 32.0 & 43.0 \\
\hline$\Sigma$ PCB's & 1.2 & 6.9 & 12.0 & 41.0 & 49.0 \\
\hline ppDDE & 1.4 & 1.2 & 3.0 & 14.0 & 85.0 \\
\hline ppDDD & 0.4 & 0.4 & 0.4 & 3.8 & 22.0 \\
\hline opDDT & nd & 0.4 & nd & nd & 0.9 \\
\hline ppDDT & 0.3 & 1.9 & nd & 7.1 & 64.0 \\
\hline$\Sigma \mathrm{DDT}^{\prime} \mathrm{s}$ & 2.1 & 4.3 & 3.4 & 25.0 & 172.0 \\
\hline$\alpha-B H C$ & 0.2 & 1.1 & 1.6 & 0.3 & 23.0 \\
\hline$y-\mathrm{BHC}$ & nd & 0.8 & nd & 2.2 & 16.0 \\
\hline t-Chlordane & 0.1 & nd & 0.1 & 0.3 & 0.4 \\
\hline c-Chlordane & nd & 0.1 & nd & 0.4 & 0.2 \\
\hline
\end{tabular}

Table 3. Rhithropanopeus harrisii. Summary of culture data for larvae fed various geographical collections of newly-hatched Artemia spp. Data presented as mean \pm one standard deviation. Means having the same grouping letter are not significantly different $(P>0.05)$. (n) sample size

\begin{tabular}{|c|c|c|c|c|c|c|c|c|c|}
\hline $\begin{array}{l}\text { Arternia } \\
\text { source }\end{array}$ & $\begin{array}{l}\text { Survival to } \\
\text { megalopa } \\
(\%)\end{array}$ & $(\mathrm{n})$ & Grouping & $\begin{array}{l}\text { Development } \\
\text { time to } \\
\text { megalopa (d) }\end{array}$ & $(\mathrm{n})$ & Grouping & $\begin{array}{c}\text { Megalopa } \\
\text { dry weight } \\
(\mu \mathrm{g})\end{array}$ & $(n)$ & Grouping \\
\hline French & $89 \pm 13$ & 60 & A & $11.1 \pm 0.2$ & 53 & A & $181 \pm 10$ & 53 & A \\
\hline Reference & $89 \pm 10$ & 60 & A & $10.9 \pm 0.2$ & $50^{\circ}$ & $\mathrm{A}$ & $166 \pm 13$ & 50 & B \\
\hline Brazilian & $85 \pm 10$ & 60 & A & $10.7 \pm 0.3$ & 53 & $\mathrm{~A}$ & $161 \pm 13$ & 53 & B \\
\hline Chinese & $84 \pm 17$ & 60 & A & $10.9 \pm 0.3$ & 51 & $\mathrm{~A}$ & $168 \pm 27$ & 51 & B \\
\hline Canadian & $72 \pm 25$ & 60 & $\mathrm{~A}$ & $11.6 \pm 0.6$ & 43 & A & $144 \pm 18$ & 43 & $\mathrm{C}$ \\
\hline
\end{tabular}


nauplii were higher (>200 $\mathrm{mg} \mathrm{g}^{-1}$, dry wt sample) than the level found in the French and Canadian populations ( $<155 \mathrm{mg} \mathrm{g}^{-1}$, dry wt sample).

All values for chlorinated hydrocarbons were below $100 \mathrm{ppb}$, except for the total DDT's in the Chinese sample (172 ppb; Table 2). Lowest levels of $\mathrm{CHC}$ were found in RAC and Brazilian collections; French and Chinese Artemia were approximately 4 to 6 times more contaminated. Despite such chemical variation no significant differences were found in the ability of the various Artemia sources to support survival and developmental rate of $R$. harrisii larvae (Table 3).

Growth rates, however, were significantly higher in crab larvae fed nauplii from the French source; the poorest growth was found in crab larvae fed Canadian brine shrimp. Growth was fastest on the French strain which contained one of the lowest lipid levels, therefore it appears that lipid levels were adequate in all Artemia strains. In addition, growth did not appear to be affected by the moderately high levels of contaminants found in the French strain. Although no significant differences were found in survival and developmental rates, the lowest mean values for survival and growth and the slowest development rate occurred with mud crab larvae fed Canadian brine shrimp nauplii. These trends suggest that the Canadian source of Artemia may be less effective in culturing larvae of $R$. harrisii.

The value of studies such as this would be of little interest if a single, reliable source of Artemia was commercially available. This has not been the case (Sorgeloos, 1980a). For example, Artemia from Macau, Brazil, which had been identified as one of the better food sources for a large variety of marine fish and crustacean larvae (Beck et al., 1980; Johns et al., 1980, 1981; Klein-MacPhee et al., 1980) are presently not commercially available (P. Sorgeloos, pers. comm.). The ISA series of studies, however, have highlighted major differences in the nutritional effectiveness of other commercially available sources of this indispensible source of food for marine and freshwater organisms (Sorgeloos et al., 1980a).

The use of Artemia of inferior quality could be an unexpected and confounding source of variation in experimental results. Although there is no ready solution to this problem, the use of RAC in experiments can give researchers a relative indication of the nutritional effectiveness of other Artemia sources they are using in the laboratory. Nauplii of the RAC have been tested for their nutritional performance in the culture of larval fish (Klein-MacPhee et al., in press) and crabs and have been found to be one of the better Artemia sources thus far tested by the ISA. The use of RAC as an intercalibration food source in experiments could reduce the number of incorrect inferences caused by the poor nutrititive value of an uncharacterized laboratory diet.

Acknowledgement. We acknowledge the technial support of W. Berry for maintenance of crab larvae and Artemia.

\section{LITERATURE CITED}

Beck, A. D., Bengtson, D. A., Howell, W. H. (1980). International Study on Artemia $V$ Nutritional value of five geographic strains of Artemia: effects of survival and growth of larval Atlantic silversides, Menidia menidia. In: Persoone, G., Sorgeloos, P., Roels, O., Jaspers, E. (eds.) The brine shrimp Artemia, Vol. 3, Ecology, culturing, use in aquaculture. Universa Press, Wetteren, Belgium, pp 249-259

Johns, D. M., Berry, W. J., Walton, W. (1981). International Study on Artemia XVI. Survival, growth and reproductive potential of the mysid, Mysidopsis bahia Molenock fed various geographical collections of the brine shrimp. Artemia. J. exp. mar. Biol. Ecol. 53: 209-219

Johns, D. M., Peters, M. E., Beck, A. D. (1980). International Study on Artemia VI. Nutritional value of geographical and temporal strains of Artemia: effects on survival and growth of two species of brachyuran larvae. In: Persoone, G., Sorgeloos, P., Roels, O., Jaspers, E. (eds.) The brine shrimp Artemia, Vol. 3, Ecology, culturing, use in aquaculture. Universa Press, Wetteren, Belgium, pp. 291-304

Klein-MacPhee, G., Howell, W H., Beck, A. D. (1980). International Study on Artemia VII. Nutritional value of five geographical strains of Artemia to winter flounder (Pseudopleuronectes americanus). In: Persoone, G., Sorgeloos, P., Roels, O., Jaspers, E. (eds.) The brine shrimp Artemia, Vol. 3, Ecology, culturing, use in aquaculture. Universa Press, Wetteren, Belgium, pp. 305-312

Klein-MacPhee, G., Howell, W. H., Beck, A. D. (In press). Comparison of a reference strain and four geographical strains of Artemia as food for winter flounder (Pseudopleuronectes americanus) larvae. Aquaculture

Manzi, J. J., Maddox, M. B. (1980). Requirements of Artemia nauplii in Macrobrachium rosenbergii (de Man) larviculture. In: Persoone, G., Sorgeloos, P., Roels, O., Jaspers, E. (eds.) The brine shrimp Artemia, Vol. 3, Ecology, culturing, use in aquaculture. Universa Press, Wetteren, Belgium, pp. 313-330

Olney, C. E., Schauer, P. S., McLean, S., Lu, Y., Simpson, K. L. (1980). International Study on Artemia VIII. Comparison of the chlorinated hydrocarbons and heavy metals in five different strains of newly hatched Artemia and a laboratory-reared marine fish. In: Persoone, G., Sorgeloos, P., Roels, O., Jaspers, E. (eds.) The brine shrimp Artemia, Vol. 3. Ecology, culturing, use in aquaculture. Universa Press, Wetteren, Belgium, pp. 343-352

Schauer, P. S., Johns, D. M., Olney, C. E., Simpson, K. L. (1980). International Study on Artemia IX. Lipid level energy content and fatty acid composition of the cysts and newly hatched nauplii from five geographical strains of Artemia. In: Persoone, G., Sorgeloos, P., Roels, O., Jaspers, E. (eds.) The brine shrimp Artemia, Vol. 3, Ecology, culturing, use in aquaculture. Universa Press, Wetteren, Belgium, pp. 365-373

Simpson, K. L., Beck, A. D., Sorgeloos, P. (1980). Workshop I. Characterization of Artemia strains for application in 
aquaculture. In: Persoone, G., Sorgeloos, P., Roels, O. Jaspers, E. (eds.) The brine shrimp Artemia, Vol. 3, Ecology, culturing, use in aquaculture. Universa Press, Wetteren, Belgium, pp. 409-411

Sorgeloos, P. (1980a). The use of Artemia in aquaculture. In Persoone, G., Sorgeloos, P., Roels, O., Jaspers, E. (eds.) The brine shrimp Artemia, Vol. 3, Ecology, culturing, use in aquaculture. Universa Press, Wetteren, Belgium, pp. $25-46$
Sorgeloos, P. (1980b). Availability of Reference Artemia cysts. Mar. Ecol. Prog. Ser. 3: 363-364

Sulkin, S. D., Norman, K. (1976). A comparison of two diets in the laboratory culture of the zoeal stages of the brachyuran crabs Rhithropanopeus harrisii and Neopanope sp. Helgoländer wiss. Meeresunters. 28: 183-190

Accepted for printing on February 26, 1982 